\title{
PEMBENTUKAN KELOMPOK USAHA BERSAMA (KUBE) BERBASIS POTENSI LOKAL DALAM RANGKA PEMBERDAYAAN MASYARAKAT
}

\section{Establishment af a Joint Business Group (KUBE) Based on Local Potential in the Framework of Community Empowerment}

\author{
Siti Nurmayanti ${ }^{*}$ Dwi Putra Buana Sakti, Eka Agustiani \\ Fakultas Ekonomi dan Bisnis, Universitas Mataram \\ Jalan Majapahit Nomor 62 Kota Mataram Provinsi NTB, 83125 \\ *Alamat korespondensi: mayaramli24@gmail.com
}

(Tanggal Submission: 24 July 2020, Tanggal Accepted: 30 Agustus 2020)

\begin{abstract}
ABSTRAK
Kegiatan pengabdian pada masyarakat sebagai salah satu bentuk dari tri dharma perguruan tinggi mengambil tema pembentukan kelompok usaha bersama (KUBE) pada pengrajin anyaman ketak dan rotan, yang masih melakukan kegiatan usaha secara individual. Tujuan pembentukan KUBE ini tentu untuk lebih memberdayakan masyarakat pengrajin ketak dan rotan yang berada di Desa Saba Kecamatan Janapria Kabupaten Lombok Tengah. Kegiatan pengabdian kepada masyarakat ini dilaksnakan atas kerjasama antara tim pelaksana kegiatan yang terdiri dari staf dosen Fakultas Ekonomi dan Bisnis Universitas Matraam dengan mahasiswa KKN Universitas Mataram yang berlokasi di Desa Saba Kecamatan Janapria Kabupaten Lombok Tengah. Kegiatan yang dilakukan terdiri dari beberapa tahap, yaitu mengidentifikasi potensi dan masalah desa, terutama terkait mengenai pembentukan kelompok usaha bersama, dan pelaksanaan program. Hasil kegiatan pemberdayaan masyarakat ini menunjukkan bahwa potensi lokal masyarakat adalah di bidang anyaman rotan dan ketak. Ketrampilan menganyam ini di miliki oleh kaum perempun Desa Saba sebagai ketrampilan turun temurun namun belum dilakukan secara professional. Kemudian dilakukan sosialisasi mengenai kelompok usaha bersama (KUBE) dengan mendatangkan nara sumber dari dinas sosial kabupaten, mensosialisasikan syarat-syarat administrasi pembentukan kelompok usaha bersama kepada ibu-ibu pengrajin anyaman. Kemudian para pengrajin di setiap dusun membentuk kelompok bersama yang terdiri dari 10 orang anggota. Para pengrajin yang seluruhnya kaum perempuan sangat antusias dan bersemangat dalam pembentukan kelompok usaha bersama di bidang anyaman ini. Hal ini tentu saja dengan harapan akan kebermanfaatan yang besar dengan bergabung dalam sebuah kelompok usaha.

Kata kunci : Pemberdayaan, Pengrajin, Pembentukan KUBE.

\section{PENDAHULUAN}

Desa Saba Kecamatan Janapria,

Kabupaten Lombok Tengah memiliki potensi di bidang kerajinan. Terutama kerajinan anyaman berbahan baku rotan dan ketak. Pengembangan potensi kerajinan ini dijadikan salah satu upaya

untuk meningkatkan kesejahteraan masyarakat, khususnya ibu rumah tangga.

$$
\text { Upaya untuk meningkatkan }
$$
kesejahteraan masyarakat ini tidak hanya menjadi tanggung jawab pemerintah saja, tetapi juga pihak lain yang terkait dengan pembangunan masyarakat, terutama perguruan tinggi.
\end{abstract}


Universitas Mataram sebagai salah satu universitas yang ada di Pulau Lombok peduli dengan program pengembangan masyarakat di perdesaan. Salah satunya melalaui program pengabdian kepada masyarakat yang bekerjasama dengan kelompok KKN mahasiswa.

Pemberdayaan masyarakat perlu digalakkan untuk meningkatkan ekonomi keluarga. Pembentukan kelompok masyarakat yang mandiri secara ekonomi berdasarkan kepentingan yang sama akan menciptakan solidaritas, kerjasama, musyawarah, rasa aman dan percaya pada diri sendiri (Sari, 2017).

Kehidupan masyarakat pengrajin di Desa Saba belum menunjukkan kondisi yang baik. Oleh karena itu diperlukan upaya untuk membantu para pengrajin meningkatkan kesejahteraannya. Salah satu upaya yang dilakukan adalah melalui pembentukan Kelompok Usaha Bersama (KUBE) di bidang anyaman rotan dan ketak.

Pemberdayaan masyarakat sangatlah penting melalui kegiatan pengabdian masyarakat Tujuan kegiatan ini adalah mengidentifikasikan potensi dan masalah masyarakat perdesaan, mendeskripsikan pelaksanaan kegiatan, dampak program KKN kepada masyarakat terutama pengrajin anyaman rotan dan ketak.

\section{METODE KEGIATAN}

Kegiatan ini dilakukan terbagi ke dalam beberapa tahap. Tahap pertama adalah mengidentifikasi potensi dan masalah masyarakat desa. Pendekatan yang digunakan secara partisipatif, dengan melibatkan warga desa dalam pertemuan di setiap dusun. Mahasiswa berperan sebagai pemandu dalam diskusi, sedangkan warga sendiri yang mengenali potensi dan menggali masalah yang dihadapi. Tahap kedua adalah sosialisasi mengenai kelompok usaha bersama dilakukan dengan mendatangkan narasumber dari dinas sosial tingkat kabupaten. Sosialisasi dihadiri oleh perangkat desa beserta perwakilan masyarakat Desa Saba, terutama masyarakat calon anggota kelompok usaha bersama. Tahap ketiga adalah pelaksanaan program. Pada program pembentukan Kelompok Usaha Bersama (KUBE) di tujukan terutama pada kaum perempuan. Kegiatan yang dilaksanakan berupa sosialisasi syarat-syarat administrasi pembentukan kelompok usaha bersama, pembentukan kelompok usaha bersama di 11 dusun di desa Saba, membuat proposal permohonan bantuan dana hibah dari Kementrian Sosial Republik Indonesia.

\section{HASIL DAN PEMBAHASAN}

\section{Identifikasi potensi dan masalah}

Kegiatan pemberdayaan masyarakat dilaksanakan melalui proses identifikasi dan masalah. Identifikasi ditujukan untuk menggali potensi sumber daya alam dan sumber daya manusia yang ada di desa. Dan identifikasi masalah merupakan upaya mencari masalah-masalah yang di hadapi oleh masyarakat desa. Tujuan mengetahui potensi dan masalah agar program pemberdayaan yang di susun sesuai dengan kondisi yang dihadapi oleh masyarakat desa. Metode yang digunakan dalam mencari potensi dan masalah ini melalui diskusi langsung dengan beberapa masyarakat desa, dan tokoh masyarakat (kepala dusun, karang taruna, ketua PKK, dII). Potensi dan masalah yang teridentifikasi misalnya, Desa Saba memiliki potensi di bidang pertanian dan peternakan, masyarakt desa terutama kaum perempuan memiliki keahlian di bidang anyaman, teruama anyaman berbahan rotan dan ketak. Selama ini kegiatan menganyam yang dilakukan oleh kaum perempuan di Desa Saba hanya untuk mengisi waktu luang. Mereka masih bekerja secara individu belum dalam kelompok. Serta belum adanya kelompok usaha bersama di bidang anyaman ini.

\section{Pelaksanaan Kegiatan Pemberdayaan Masyarakat}

Pelaksanaan kegiatan pemberdayaan masyarakat pengrajin anyaman rotan/ketak di 
Desa Saba berdasarkan hasil identifikasi potensi dan masalah yang telah di sebutkan sebelumnya. Terdapat beberapa program kegiatan yang dilakukan terutama di bidang kerajinan ini. Pertama, kegiatan sosialisasi mengenai pentingnya para pengrajin anyaman tergabung dalam sebuah kelompok untuk mendapatkan manfaat yang lebih besar. Kedua, sosialisasi mengenai kelompok usaha bersama (KUBE) dari dinas sosial kabupaten. Ketiga, mensosialisasikan syarat-syarat administrasi pembentukan kelompok usaha bersama kepada ibu-ibu pengrajin anyaman. Keempat, para pengrajin di setiap dusun membentuk kelompok bersama yang terdiri dari 10 orang anggota. Kemudian memilih diantara mereka siapa yang berperan sebagai ketua kelompok, sekretaris dan bendahara. Kelima, pembuatan proposal permohonan bantuan dana hibah untuk perkembangan usaha kepada Kementrian Sosial Republik Indonesia melalui Dinas Sosial Provinsi.

Para pengrajin yang seluruhnya kaum perempuan sangat antusias dan bersemnagat dalam pembentukan kelompok usaha bersama di bidang anyaman ini. Hal ini tentu saja dengan harapan akan kebermanfaatan yang besar dengan bergabung dalam sebuah kelompok usaha.

Namun beberapa kendala yang dihadapi adalah; ada beberapa pengrajin yang masih ragu untuk bergabung karena belum terlalu paham dengan kelompok usaha besama, belum yakinnya para pengrajin terutama yang dipilih sebagai ketua, sekretaris dan bendahara dalam menjalankan kelompok usaha bersama ini, dan modal usaha yang masih terbatas.

\section{Dampak Pelaksanaan Kegiatan Pemberdayaan Masyarakat}

Pelaksanaan kegiatan pengabdian kepada masyarakat memberikan dampak positif kepada masyarakat. Dampak yang dirasakan masyarakat bersifat langsung maupun tidak langsung. Misalnya Desa Saba mengetahui potensi masyarakatnya terutama kaum perempuan di bidang anyaman rotan dan ketak; Desa Saba terbantu dengan program pemberdayaan masyarakat yang dilakukan oleh tim pelaksana yang bekerjasama dengan kelompok mahasiswa KKN Universitas Mataram terutama dalam pembentukan kelompok usaha bersama di bidang anyaman rotan dan ketak; para pengrajin tidak lagi bekerja secara individu namun bekerja secara kelompok sehingga akan mampu meningkatkan jumlah produksi yang akan berimbas pada peningkatan pendapatan; memperoleh pengetahuan mengenai bagaimana bekerja dalam kelompok usaha bersama sehingga akan lebih terjalin rasa kekompakan dan persaudaraan; akan lebih mudah untuk mendapatkan bantuan usaha dari pihak terkait; terbantu dalam pembuatan proposal bantuan hibah untuk kelangsungan usaha kelompok pengrajin anyaman rotan dan ketak.

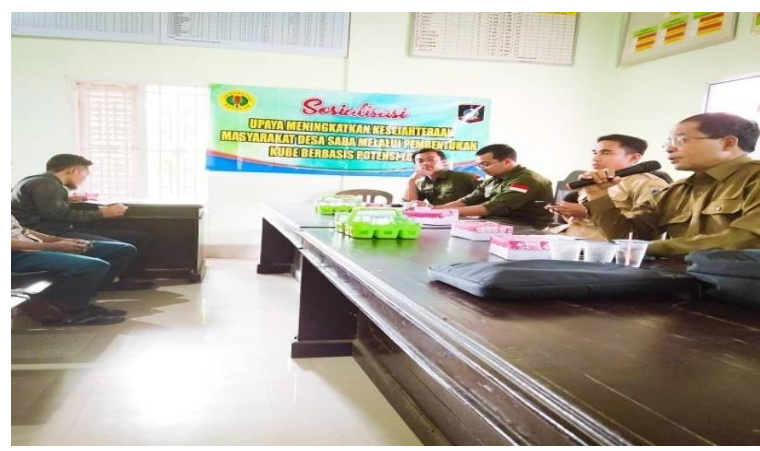

Gambar 1. Sosialisasi Pembentukan KUBE

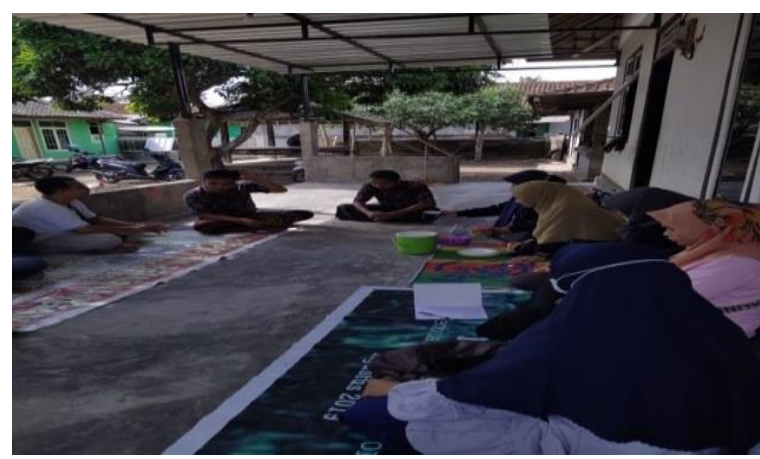

Gambar 2. Pembentukan KUBE

\section{KESIMPULAN}

Pelaksanaan kegiatan Pengabdian kepada masyarakat bekerjasama dengan kelompok mahasiswa KKN Universitas Mataram di Desa Saba 
Kecamatan Janapria Kabupaten Lombok Barat telah berhasil melakukan pembentukan kelompok usaha bersama (KUBE) di bidang anyaman rotan dan ketak. Kelompok Usaha Bersama (KUBE) ini beranggotakan ibu-ibu rumah tangga yang memiliki ketrampilan menganyam rotan dan ketak sebagai ketrampilan turun temurun. Diharapkan dengan terbentuknya KUBE ini akan dapat meningkatkan pendapatan masyarakat sehingga kesejahteraan akan semakin meningkat.

\section{DAFTAR PUSTAKA}

Departemen Sosial RI, 2010. Dampak Sosial Ekonomi Program Penanganan
Kemiskinan melalui KUBE, Sosial Masyarakat, Badan Pelatihan dan Pengembangan, Jakarta.

Saputra, L Alan Tirangga, Syahby, Amar Rachman, et al, 2020, "Upaya Peningkatan Kesejahteraan Masyarakat Melalui Pembentukan Kelompok Usaha Bersama Berbasis Potensi Lokal Desa Saba", Laporan KKN Tematik KUBE Desa Saba 2020

Sari, Purnama, 2017, Kelompok Usaha Bersama (KUBE) Dalam Rangka Pemberdayaan Masyarakat Prasejahtera, Moderat:Jurnal IImiah IImu Pengetahuan, Vol 3.No. 2. 